\title{
Pseudoartrosis maxilar superior post-cirugía ortognática. A propósito de un caso clínico
}

\author{
Post surgical orthognathic of upper maxilla pseudoarthrosis. \\ Proposed clinical study
}

\author{
I. Zubillaga Rodríguez' ${ }^{1}$ I. Heras Rincón², J.J. Montalvo Moreno3
}

Resumen: Introducción. La introducción de nuevos métodos de fijación rígida en el tratamiento de fracturas faciales durante los últimos 25 años ha incrementado no sólo el arsenal terapéutico disponible sino también, cuando no es correctamente utilizado, el tipo de complicaciones postquirúrgicas. Material y métodos. Presentamos un nuevo caso clínico con el diagnóstico de pseudoartrosis de maxilar superior tras la realización de una osteotomía convencional tipo LeFort I en el seno de un procedimiento de cirugía ortognática. Discusión. El retardo de consolidación- pseudoartrosis puede resultar tras el tratamiento incorrecto de fracturas faciales con miniplacas-tornillos de titanio. Sin embargo, y tras revisar la literatura existente, el tratamiento de dichas complicaciones no ha variado de forma significativa durante los últimos años. El objetivo es la inmovilización mecánica en el foco de fractura afecto. En ocasiones, y dependiendo del tipo de consolidación obtenida, se necesita recurrir a la obtención de injertos óseos antólogos. La clasificación clínica de los defectos-consolidaciones óseas anómalas es a menudo arbitraria. Existe un amplio espectro de definiciones que describen condiciones concurrentes simultáneas e implicaciones funcionales determinadas por la localización anatómica. Se discuten los distintos conceptos relacionados con la consolidación ósea. Conclusiones. La estabilización inadecuada de las fracturas con tratamiento conservador o métodos de fijación rígida conduce a infección, pseudoartrosis o ambos. La solución pasa por por la fijación estable de la fractura. Dependiendo del defecto creado, la osteosíntesis o reosteosíntesis que es necesaria debe ser acompañada por un injerto de hueso antólogo esponjoso, restaurando la oclusión dental adecuada.

Palabras clave: Pseudoartrosis; Retardo de consolidación; Cirugía ortognática.

Recibido: 9.02.2007

Aceptado: 16.03.2009

1 Médico Adjunto

2 Médico Residente

3 Jefe de Servicio

Servicio de Cirugía Oral y Maxilofacial

Hospital Universitario 12 de Octubre. Madrid. España

\section{Correspondencia:}

Servicio de Cirugía Oral y Maxilofacial

Hospital Universitario 12 de Octubre

Avda de Córdoba s/n 28041 Madrid. España

e-mail: ignaciozubillaga@yahoo.es
Abstract: Introduction. The development of rigid internal fixation in the management of facial fractures over the last 25 years increased not only the number of available treatments but also, when incorrectly applied, the types of complications arising. Material and methods. We present a new case report of upper jaw pseudoarthrosis after a convencional treatment of orthognatic surgery ( osteotomy type LeFort I). Discussion. Pseudarthrosis-nonunion can result after incorrect treatment of facial fractures with titanium miniplatesscrews. When we review the publishing literature, we find that the correct treatment of this potential pitfalls has not changed significantly during last years. The aim is the mechanical immobility of the created fracture. Sometimes we must harvest cancellous bone graft to complete the treatment. We discuss the different terms related to anomalies in the ossification. Conclusions. Inadequate stabilization of fractures by either conservative or operative methods often leads to infection, pseudoarthrosis or both. To promote healing of both infections and pseudarthrosis, absolutely stable fixation of the fragments is necessary. Depending on the defect zones that may develop, the osteosynthesis or reosteosynthesis that is usually necessary must be accompanied by a graft of autogenous cancellous bone.

Key words: Pseudarthrosis; Delayed union; Orthognatic surgery. 


\section{Introducción}

La introducción de nuevos métodos de fijación rígida en el tratamiento de fracturas faciales durante los últimos 25 años ha incrementado no sólo el arsenal terapéutico disponible sino también, cuando no es correctamente utilizado, el tipo de complicaciones postquirúrgicas. El retardo de consolidación- pseudoartrosis puede resultar tras el tratamiento incorrecto de fracturas faciales con miniplacas-tornillos de titanio.

Sin embargo, y tras revisar la literatura existente, el tratamiento de dichas complicaciones no ha variado de forma significativa durante los últimos años.

El objetivo es la inmovilización mecánica en el foco de fractura afecto. En ocasiones, y dependiendo del tipo de consolidación obtenida, se necesita recurrir a la obtención de injertos óseos antólogos.

La absoluta mayoría de casos clínicos descritos en relación a osificación anómala en el foco de fractura se producen tras el tratamiento inapropiado de fracturas faciales. Se presenta y discute a continuación un caso clínico de pseudoartrosis de maxilar superior tras un procedimiento quirúrgico convencional de cirugía ortognática (osteotomía maxilar superior tipo Le Fort I).

\section{Caso clínico}

Mujer de 39 años ingresada para tratamiento quirúrgico de deformidad dentofacial. Entre sus antecedentes personales destaca anemia ferropénica, sin presentar ninguna alergia medicamentosa conocida. A la exploración física se aprecia un prognatismo marcado con una clase III molar y pseudohipoplasia de maxilar superior. A la paciente se le realizó una ortopantomografía y telerradiografía lateral de cráneo, iniciando el estudio cefalométrico correspondiente.

Tras tratamiento ortodóncico y extracción de los 4 cordales se somete a la paciente a intervención de cirugía ortognática convencional bajo anestesia general e intubación nasotraqueal en la que se realiza osteotomía tipo LeFort I fijada con dos placas preformadas de titanio en ambos arbotantes naso maxilares con avance de $7 \mathrm{~mm}$, impactación anterior de $3 \mathrm{~mm}$ y posterior de $5 \mathrm{~mm}$, rotación izquierda de $1 \mathrm{~mm}$, resección parcial inferior de septum nasal, cincha de alares y cierre labial en V-Y (Fig. 1).

La paciente fue dada de alta y seguida en revisiones en consultas externas evidenciándose episodios de celulitis genianas bilaterales de repetición. Su inicio se produjo a los 6-9 meses de la intervención inicial. Se decide reintervenir a la paciente 1 año después de la primera intervención y retirar el material de osteosíntesis a nivel de la osteotomía LeFort I tras reapertura del abordaje sublabial superior bilateral previo. Intraoperatoriamente no se objetiva movilidad del tercio medio facial a nivel de la osteotomía tipo LeFort I y se cataloga dicho episodio quirúrgico como una intolerancia al material de osteosíntesis.
However, when we review the published literature, we find that the correct treatment of these potential pitfalls have not significantly changed over the past few years. The aim is the mechanical immobility of the center of the created fracture. Sometimes, depending $n$ the type of obtained consolidation, we resort to obtaining bone grafts.

The majority of the clinical cases described in relation to abnormal ossification of the created fracture occur after inappropriate facial fracture treatment. Below we discuss the case of pseudarthrosis of the superior maxilla after a conventional orthognathic surgical procedure (Superior maxilla osteotomy type Le Fort I).

\section{Clinical Case}

Woman 39 years old, admitted for surgical treatment of a dental facial deformity. Her medical history showed that she was anemic and had no known allergies to medication. Upon physical examination the prognosis is class 3 molar and pseudo hipoplasia of the superior maxilla. A cranial orthopantography and teleradiography were carried out at the start of the corresponding cephalometric study.

After orthodontic treatment and extraction of the 4 wisdom teeth the patient underwent orthognathic conventional surgery. Under local anesthetic and nasal/tracheal tube for intubation and osteotomy type Le Fort I was performed. The bones were fixed with 2 premade titanium plates in both nasal maxilla outriggers $7 \mathrm{~mm}$ of adavance, $3 \mathrm{~mm}$ of anterior impaction and $5 \mathrm{~mm}$ of posterior impaction, $1 \mathrm{~mm}$ left rotation, partial inferior nasal septum resection, alar cinching and labial closure in V-Y fashion (Fig. 1).

The patient was released and had follow up external consults that showed episodes of repeating bilateral cellulitis. It started 6-9 months after the initial intervention. It was decided that the patient have the osteosythesis material removed one year after the initial intervention. This is done by reopening of the previous bilateral superior sub labial approach. Between operations we attempt not to move the third half 
Tras seguir revisiones periódicas dentro de la normalidad tanto en nuestras consultas externas como con el ortodoncista, un año después de la última intervención quirúrgica la paciente refiere disminución de fuerza con la masticación, impidiendo la práctica de una dieta con alimentos sólidos. En la exploración clínica se aprecia leve movilidad del maxilar superior a nivel del LeFort I, manteniendo la paciente una oclusión correcta en clase I. En la TC de tercio medio facial solicitado se observa ausencia de consolidación en el maxilar superior con solución de continuidad ósea en la osteotomía LeFort I (Fig. 2). Dado el tiempo de evolución desde la primera intervención se establece el diagnóstico de presunción de pseudoartrosis de maxilar superior en dicha osteotomía.

Se decide reintervenir a la paciente para el manejo definitivo de dicha complicación. Tras realizar un bloqueo intermaxilar elástico en clase I y reabrir de nuevo el abordaje sublabial superior previo (Fig. 3), se retira el tejido fibroso interpuesto en los márgenes óseos a nivel de la osteotomía maxilar superior (Fig. 4). Se fija la osteotomía maxilar superior mediante dos placas preformadas de titanio con el avance inicialmente establecido (Fig. 5). Se obtienen injertos óseos esponjosos de tibia derecha a través de un abordaje medial (Fig. 6) y se colocan los mismos en el gap óseo de la osteotomía Le-Fort I sellando dicho defecto (Fig. 7). El estudio anatomopatológico del tejido localizado en el foco interfracturario revela la presencia de células cartilaginosas en el interior de un tejido con predominante proliferación fibroblástica.

Tras dicha intervención es seguida en nuestras consultas apreciándose la consolidación a nivel de la osteotomía, sin movilidad de la misma, con una oclusión estable y aspecto estético favorable. Asimismo no se apreciaron complicaciones tras la toma del injerto tibial, siendo favorable su Rx de control (Fig. 8).

\section{Discusión}

La clasificación clínica de los defectosconsolidaciones óseas anómalas es a menudo arbitraria. Existe un amplio espectro de definiciones que describen condiciones concu-

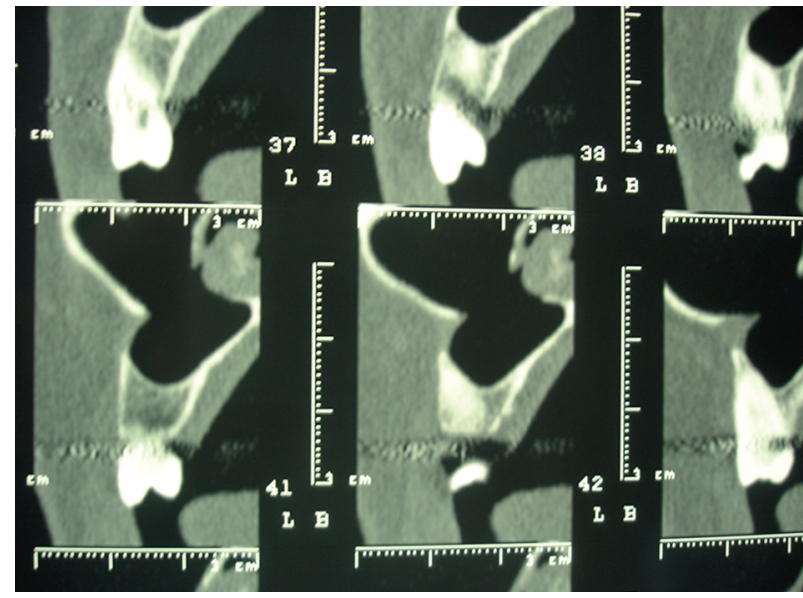

Figura 2. TC sagital donde se objetiva la ausencia de consolidación ósea en el LeFort I.

Figure 2. Sagital TC where an abscence of bone consolidation in a LeFort I is checked.

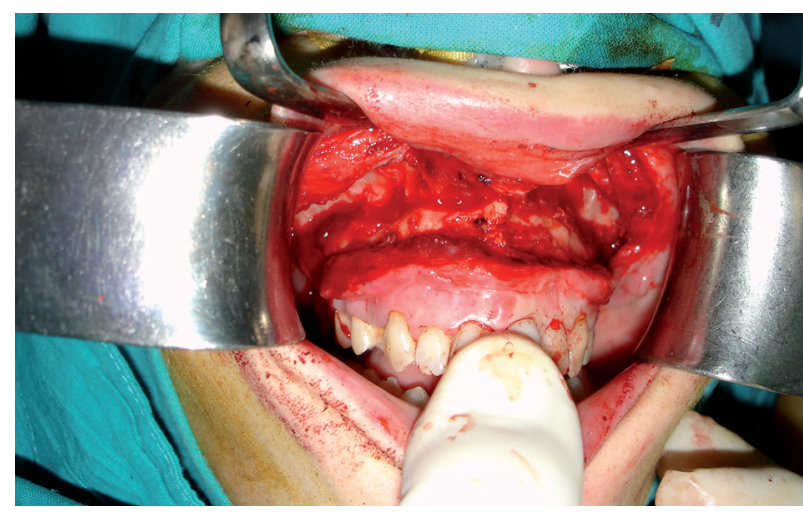

Figura 3. Imagen clínica de la pseudoartrosis maxilar superior. Figure 3. Clinical image of the upper maxilla pseudoarthrosis.

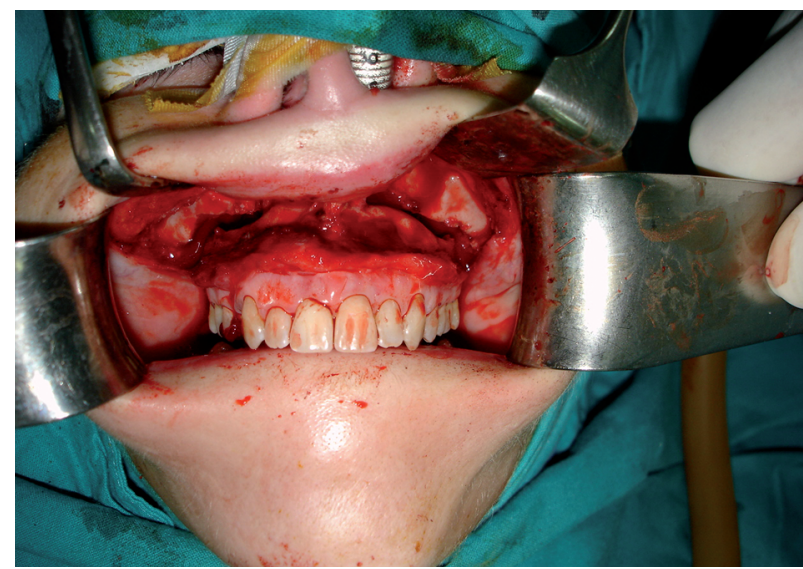

Figura 4. Aspecto clínico de la osteotomía de LeFort I tras la exéresis del tejido fibrocartilaginoso.

Figure 4. Clinical aspect of osteotomy of Le fort I after fibro cartilage tissue abscission.

of the face even with the Le Fort I osteotomy. This surgery is categorized as intolerance to osteosynthetic material.

One year after having periodic revisions in our external consults as well as with the orthodontist the patient reported exerting less force when chewing which allowed her to have solids in her diet. Clinical exploration showed light movement of the superior maxilla even with the Le Fort I, the patient maintains correct occlusion of class I. In the computed tomography of the facial middle third we observe an absence of superior maxilla consolidation with continued bone reme$d y$ of the Le Fort osteotomy (Fig. 2). Given the evolution time since the first intervention, a diagnostic hypothesis of superior maxilla pseudoarthrosis of this osteotomy is established. A decision is made to operate on the patient again in order to have definitive management of this complication. After blocking the elastic inter maxilla in class I and reopening the new superior sub labial approach, the fibrous tissue in the bone margins of the superior maxilla osteotomy is removed (Fig. 4). The superior osteotomy maxilla is attached using two preformed titanium plates in which the advance is already established (Fig. 5) Spongy bone grafts are obtained from the right tibia using a medial approach (Fig. 6.) The grafts are then placed in the bone gap of the Le Fort I osteotomy, closing the defected area (Fig. 7). The anatomic pathological study of the localized fracture tissue shows a presence of cartilaginous cells with predominant fibroblast pro- 
rrentes simultáneas e implicaciones funcionales determinadas por la localización anatómica. ${ }^{1}$

Se denomina retardo de consolidación al fracaso de la curación durante los 4-6 primeros meses tras el tratamiento aplicado. El tiempo varía según las diversas series revisadas, aunque por consenso se establecer la fecha de 6 meses como referencia. Dicho término se deriva de observaciones- estudios histológicos realizados en el esqueleto óseo. Las investigaciones acerca de la consolidación ósea en maxilares de oveja muestran que el proceso de curación es idéntico al del resto del esqueleto. Existe eventualmente una aceptable estructura ósea consolidada. A diferencia de la ausencia de unión, presenta potencial para la consolidación ósea tras una inmovilización adicional y una adecuada reducción.

Se define como pseudoartrosis (no unión) aquellas fracturas en las cuales no se ha producido la curación-osificación tras 6 meses post-tratamiento (para algunos autores el límite son 8 meses). Son auténticas falsas articulaciones en las que el tejido interfragmentario hallado es fibrocartílago. ${ }^{1}$ Mientras que la formación ósea (mineralización) continua en el retardo de consolidación, este proceso finaliza en los casos de ausencia de unión. Existe una ausencia permanente de tejido óseo identificable en el foco de fractura. Estudios experimentales en animales (Schenk y Willenegger) ${ }^{2}$ han mostrado que el fibrocartílago interfragmentario es un tejido vivo pero no vascularizado. La movilización continua entre los fragmentos de la fractura impide la mineralización del fibrocartílago.

Es preciso distinguir entre pseudoartrosis hipertrófica, donde existe vascularización objetivable en la formación del callo óseo, y pseudoartrosis atrófica (no unión sin formación de callo óseo), relacionada con el insuficiente aporte vascular. Ambas pueden ser distinguidas radiologicamente. En la forma hipertrófica, los extremos de los fragmentos están característicamente engrosados (denominados como pies de elefante) mientras que en la forma atrófica los extremos simulan una osteoesclerosis. Dependiendo de si existen procesos asociados infecciosos de forma intermitente o crónica, observaremos pseudoartrosis con contacto o con gap óseo interfragmentario. Figure 6. Spongy tibia graft. lar superior.

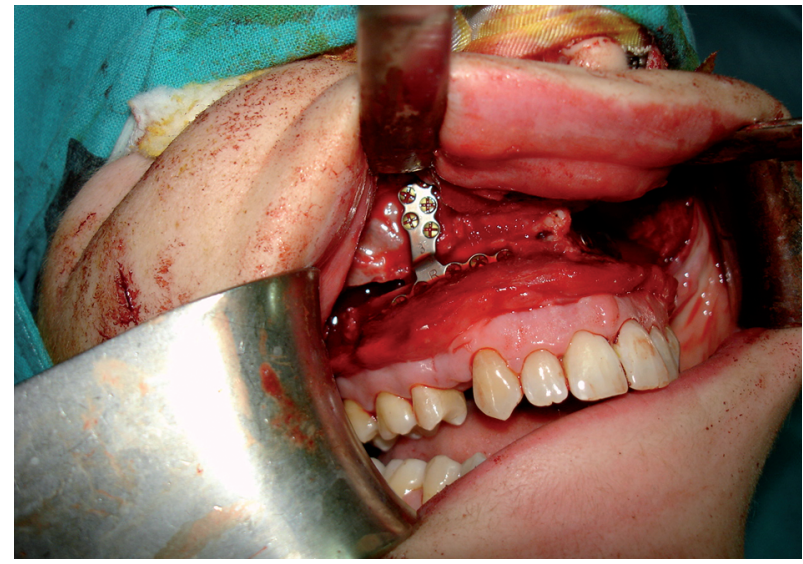

liferation on the inside of the tissue.

After said intervention our consults show consolidation at osteotomy level, without its movement, with stable occlusion and an aesthetically pleasing aspect. In like manner complications after taking the graft from the tibia were not valued, being that the Rx control was favorable (Fig. 8).

Figura 5. Nueva osteosíntesis maxilar superior.

Figure 5. New upper maxilla osteo synthesis.

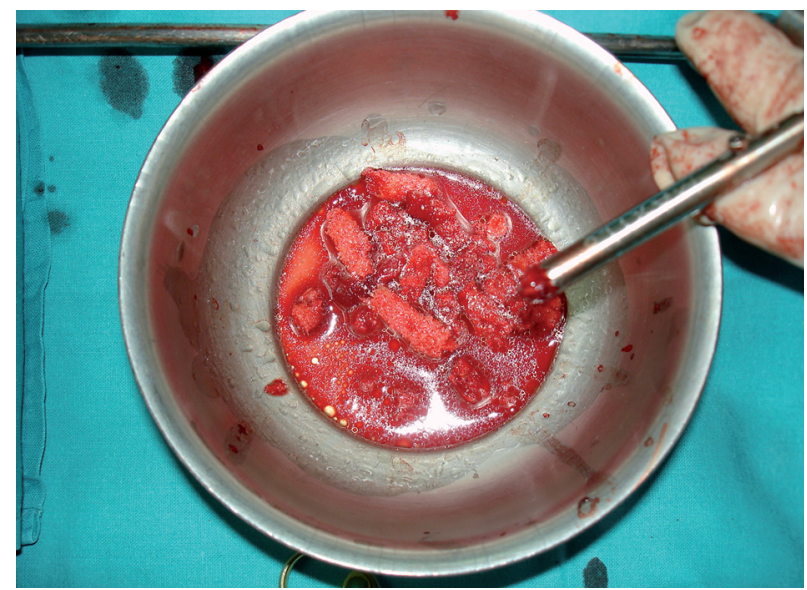

Figura 6. Injerto esponjoso tibial.

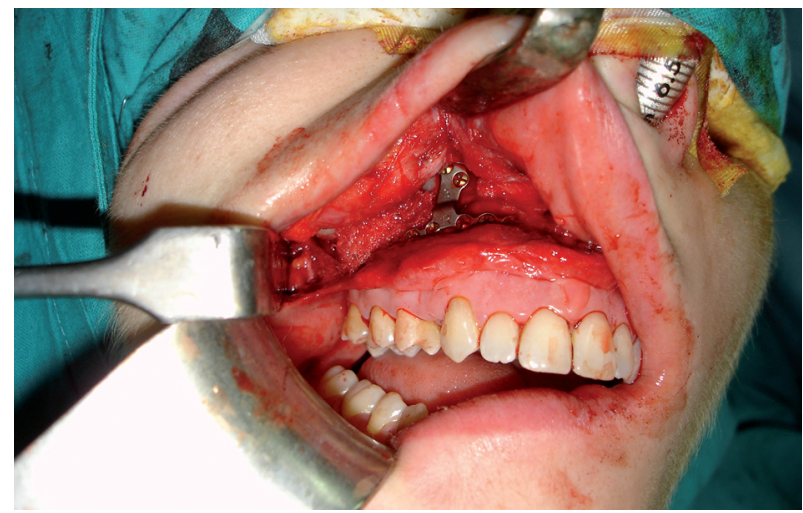

Figura 7. Colocación de injerto esponjoso tibial en defecto maxi-

Figure 7. Placement of spongy tibia graft in upper maxilla defect.

\section{Discussion}

The clinical classification of unusual bone consolidation defects is regularly arbitrary. There is wide spectrum of definitions that describe concurrent simultaneous conditions and functional implications that are determined by anatomic position. ${ }^{1}$

Failure to cure during the first 4-6 months after applied treatment is called lack of consolidation. The time varies according to the diverse reviewed series. Although the common time used as a reference is 6 months. This time is derived from the observations and histological study done on skeletal bone. Investigations into the maxilla bone consolidation of sheep show that the healing process is identical to that of the rest of the skeleton. Eventually there is an acceptable consolidated bone structure. Unlike the absence of union, there is potential for bone consolidation after additional immobilization and adequate reduction.

Fractures that do not have ossification after 6 months of post operative treatment are defined as pseudoarthrosis (some authors increase the limit to 8 months). The articulated joints where the chipped tissue discovered is fibrocartilage are false joints. While the bone formation continues in delayed union, 
La osteomielitis en el gap óseo puede suceder tras el tratamiento conservador o quirúrgico. La estabilización inadecuada del foco de fractura con fijación interna puede resultar particularmente en inflamación. En cualquier fractura donde se aplique fijación interna, el resultado definitivo puede variar desde la unión ósea hasta el fracaso del implante. Si el fracaso ocurre antes del final de la fase de consolidación ósea un callo visible radiológicamente se formará con la reaparición posterior de un gap óseo tras la reabsorción de los extremos de la fractura. Ya que el

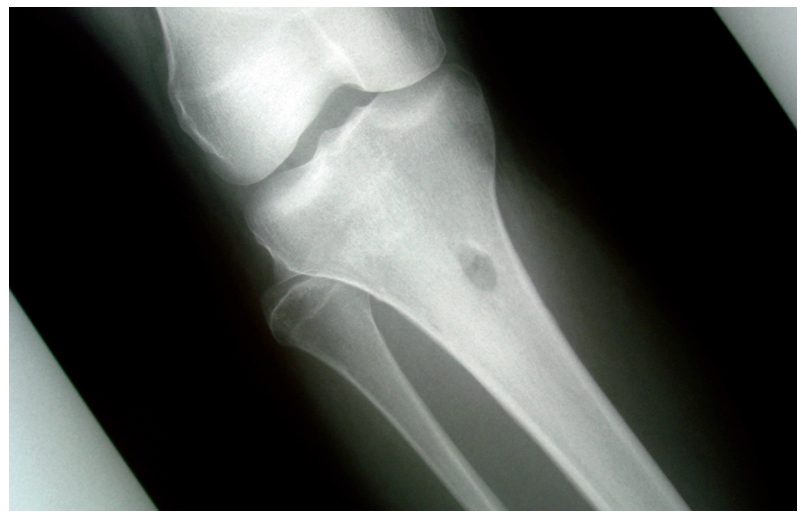

Figura 8. RX control tras toma de injerto tibial. Figure 8. Rx control after removing tibia graft. this process ends in the cases that have a lack of union. There is a permanent lack of identifiable bone tissue in the center of the fracture. Experimental studies on animals (Schenk and Willenegger) ${ }^{2}$ have shown that the chip of fibro cartilage is live tissue but it is not vascularized. The continual mobilization between the fracture fragments allows for fibro cartilage mineralization. It's important to distinguish between hypertrophic es la estabilización de la fractura, deben asegurar una completa garantía de estabilidad. El movimiento en presencia de cuerpos extraños generalmente implica no sólo pseudoartrosis sino también infección local. ${ }^{3}$

La ausencia de unión implica una alteración en el proceso normal de curación ósea. Mientras que la curación en las fracturas tratadas de forma conservadora ocurre predominantemente vía formación de callo óseo desde el periostio, el objetivo de la fijación estable de las fracturas debe ser la curación ósea directa desde la cortical, con las osteonas puenteando directamente el gap óseo. ${ }^{4}$ La inestabilidad mecánica altera este proceso y puede provocar el retardo de consolidación o la ausencia de unión y, en la presencia de cuerpos extraños, procesos infecciosos.

La conminución en el foco de fractura implica dificultad añadida a la hora de la fijación y por tanto mayor frecuencia de pseudoartrosis. La alteración de la microcirculación en el hueso y los micromovimientos simultáneos causados por la insuficiente estabilidad son los principales factores que conducen a la ausencia de unión. En relación a las técnicas de fijación interna todavía no ha sido establecido cúal de los dos componentes (microcirculación vs micromovimientos) es más importante.

No existe duda en el momento actual que la aplicación de materiales de osteosíntesis modifica la microcirculación. Experimentos animales en perros y ovejas han mostrado que la vascularización es reducida bajo placas fijadas con tornillos bicorticales (compresión estática). Con una reducción inadecuada y una osteosíntesis incorrectamente realizada, la vascularización endóstica es también alterada por el micro-macromovimiento de los fragmentos y la consolidación normal en el gap de la fractura no puede suceder a través de una curación secundaria. ${ }^{5}$ La formación del callo intraóseo puede exacerbar la situación comprimiendo las cavidades medulares y adicionalmente obstruyendo la vascularización.

Además, múltiples factores pueden estar inplicados en la génesis de una ausencia de consolidación en el foco de fractura, incluyendo el fracaso del tratamiento antibiótico, el retraso en el tratamiento, la presencia de múltiples fracturas, cuerpos extraños en el foco de fractura, edad del paciente, alteraciones metabólicas y abuso de drogas y alcohol. Dichos factores suelen asociar una malnutrición, con efectos adversos en la curación ósea. Topazian y Goldberg, ${ }^{6}$ presentan una alta tasa de complicaciones en la población indigente en pseudoarthrosis, where there is objectivable vascularization in bone callus formation, and atrophic pseudoarthrosis (non union without bone callus formation), related to the insufficient vascular contribution. Both types of pseudoarthrosis can be radio logically distinguished. In hypertrophic pseudoarthrosis the ends of the fragments are typically swollen(called elephant feet) while in atrophic pseudoarthrosis the ends simulate osteosclerosis. Depending on if the associated infected processes are intermittent or chronic, we see pseudoarthrosis either with contact or with a bone interfragment gap.

Osteomyelitis in the bone gap can occur after conservative or surgical treatment. Inadequate treatment of the fracture with internal fixation can result in inflammation. In any fracture where internal fixation was used, the definitive result can vary from bone union to a failed implant. If the failure happened before the end of the bone consolidation phase a radio logically visible callus will form with posterior repair of the bone gap after reabsorbtion of the ends of the fracture. Since the purpose of using plates and screws is to stabilize the broken bone fragments it should completely guarantee stabilization. Movement when foreign bodies are present generally implies not only pseudoarthrosis but also infection of the area. ${ }^{3}$

The absence of union implies an alteration to the normal bone healing process. While the conservative healing of treated fractures occurs mainly via callus formation from the periosteum, the objective of stable fixation of the fractures should be direct bone healing from the cortical and osteons directly bridging the bone gap. ${ }^{4}$ Mechanical instability alters this process and can provoke delayed consolidation or absence of union and, when foreign bodies are present, infectious processes.

Comminution at the center of the fracture involves added difficulty during fixation and because of this a higher incidence of pseudoarthrosis. Alteration of bone microcirculation and the simultaneous micro movements caused by insufficient stability are the main factors that lead to non union. It has yet to be established which of the components of internal fixation techniques (microcirculation or micro movements) are more important.

At the moment there is no doubt that applying osteosynthetic materials modifies microcirculation. Experiments per- 
los que el seguimiento clínico postoperatorio es complejo. La ausencia de cooperación y la deficitaria higiene empeora el pronóstico. Es crucial el análisis de dichos factores que dan lugar al fracaso de consolidación y que evitan la osificación adecuada de la fractura.

Hemos de considerar de forma independiente otro factor implicado en la ausencia de unión: la osteomielitis. La asociación de infección con ausencia de osificación ha sido descrita en las series como elevada. La infección afecta a la curación ósea, reduciendo la oxigenación y favoreciendo la proliferación de fibroblastos, con retardo de la actividad osteoblástica y osteoclástica. La formación de tejido fibroso prevalece sobre el depósito óseo, creando una ausencia de consolidación.

Anderson y Alpert, 7 consideran que la infección puede ser evitada instaurando un tratamiento quirúrgico precoz. La antibioterapia pre-postoperatoria puede ayudar a reducir la tasa de infección.

Aunque parezca un tópico, el mejor tratamiento consiste en evitar la complicación.

Tras revisar la literatura, obtenemos una incidencia de pacientes con ausencia de consolidación en el foco de fractura de aproximadamente el $3 \%$, incidencia semejante a revisiones realizadas hace 20 años. ${ }^{7,8} \mathrm{El}$ dato es sorprendente teniendo en cuenta la evolución surgida en los métodos de fijación de los que disponemos en el momento actual( no existen series de pacientes con retardoausencia de consolidación en maxilar superior, de manera que los datos son referidos a fracturas de maxilar inferior tratadas quirúrgicamente mediante reducción y osteosíntesis).

La ausencia de fijación o la fijación incorrecta de las fracturas provoca que el proceso inflamatorio local que se establece en el foco fracturario difunda endósticamente como consecuencia de la limitada perfusión en los extremos óseos de la fractura. Como resultado, la osteomielitis en el gap óseo puede asociarse.

Independientemente de que se trate de una osteomielitis (frecuentemente asociada a la ausencia de consolidación) alrededor del foco de fractura o de una pseudoartrosis sobreinfectada o no, el objetivo principal debe ser la absoluta estabilización del fracturario. La revisión de estudios clínicos nos desvela que las placas de titanio pueden ser aplicadas incluso en focos de fractura con inflamación siguiendo una técnica quirúrgica adecuada. ${ }^{9}$ Se recomiendan tres medidas básicas en el manejo de dichas situaciones:

1. Antibioterapia específica.

2. Reducción anatómica, en caso de fracturas faciales.

3. Fijación estable con placas y tornillos de titanio.

4. Empleo de injertos óseos de hueso autólogo en el foco de fractura si fuera preciso.

Es cierto que el bloqueo intermaxilar aplicado como único método de estabilización da lugar a una regresión de la inflamación, pero habitualmente provoca una extensa reabsorción de los fragmentos distales de la fractura, resultando generalmente en pseudoartrosis. Es precisa una fijación interna rígida para completar el tratamiento, asegurando una oclusión correcta y estable.

El tratamiento de la pseudoartrosis, especialmente si presenta defecto óseo, implica no sólo una fijación interna rígida sino también injertos óseos antólogos que reconstruyan el gap óseo creado. Cualquier secuestro o tejido interfragmentario debe ser extraído y los fragmentos distales de la fractura deben ser cureteados. ${ }^{10}$ formed on dogs and sheep showed that vascularization is reduced when using plates fixed with bi cortical screws (static compression). When reduction is inadequate and osteosynthesis is not carried out properly, the endostic vascularization is also altered because of the micro-macro movement of the bone fragments. Normal consolidation of the fracture gap can not take place through secondary treatment. ${ }^{5}$ Intrabone callus formation can aggravate the situation compressing the medullar cavities and additionally obstructing vascularization.

Furthermore, there can be many factors involved in the genesis of a lack of consolidation at the center of the fracture. These factors include failed antibiotic treatment, delayed treatment, the presence of many fractures, foreign bodies at the center of the fracture, patient age, metabolic alterations, and drug and alcohol abuse. These factors are usually associated with malnutrition and have adverse affects on bone treatment. Topazian and Goldberg6 show a high complication rate among indigenous populations that had complex postoperative clinical follow-up. The lack of cooperation and the hygiene deficit also make the prognosis worse. It is crucial to analyze the factors that cause failed consolidation and prevent adequate ossification of the fracture.

Osteomyelitis is another factor that should be independently considered as being involved in the lack of union. Lack of ossification and infection has been described as highly associated. Infection affects the bone treatment, reducing oxygenation, increasing fibroblast proliferation and delaying osteoblastic and osteoclastic activity. Formation of fibrous tissue prevails over bone deposit which creates a lack of consolidation.

Anderson and Alpert' consider that infection can be avoided by establishing early surgical treatment.

Like many things, the best treatment is to prevent the problem before it starts. Reviewing the literature we find the number of patients with lack of consolidation at the center of the fracture to be $3 \%$. That number is similar to the revisions performed 20 years ago. 7,8 This is surprising taking into account the evolution that has taken place in fixation methods that are available today (there are no series about patients with delayed consolidation in the upper maxilla, which means the statistics that we have were taken from lower maxilla fractures that were treated by surgical reduction or osteo synthesis).

Lack of fracture fixation or incorrect fracture fixation causes the local inflammatory process that takes place at the center of the fracture to endostically spread out. This happens as a result of limited perfusion of the sides of the bone fracture. As a result, osteomyelitis of the bone gap can be associated.

Regardless of whether there is osteomyelitis (often associated with lack of consolidation) around the center of the fracture or a over infected pseudoarthrosis the main goal should be the complete stabilization of the fracture. Review of clinical studies shows that the titanium plates can be used even in the center of an inflamed fracture if a proper technique is used. ${ }^{9}$ Three basic methods are recommended to handle these situations: 
La inestabilidad combinada con la fatiga del material de osteosíntesis o con la contaminación continua del gap óseo en presencia de defectos de tejidos blandos constituye a menudo la causa de una pseudoartrosis crónica infectada. Una fijación anómala de un único tornillo de osteosíntesis puede ser el responsable de la inflamación crónica. El tratamiento de elección en estos casos consiste en el reemplazo del material de osteosíntesis habitualmente por nuevas placas de titanio (según la zona a puentear, en ocasiones es preciso el empleo de placas que soporten la carga ,como en mandíbula) con cobertura antibiótica e injertos óseos si son precisos.

\section{Conclusiones}

Hoy en día, en nuestro arsenal terapéutico contamos con métodos precisos de fijación interna rígida. A pesar de dichas sofisticaciones, se siguen presentando nuevos casos de ausencias-retardos de consolidación ósea en focos de fractura, requiriendo tratamientos complementarios. Un análisis crítico del proceso patológico es preciso de forma previa a la cirugía correctora. Una completa y bien documentada exploración física, técnicas de imagen y un conocimientos de las técnicas quirúrgicas empleadas son básicos a la hora de plantear el tratamiento definitivo. ${ }^{11}$

La estabilización inadecuada de las fracturas con tratamiento conservador o métodos de fijación rígida conduce a infección, pseudoartrosis o ambos. La solución pasa por la fijación estable de la fractura. Dependiendo del defecto creado, la osteosíntesis o reosteosíntesis que es necesaria debe ser acompañada por un injerto de hueso antólogo esponjoso, restaurando la oclusión dental adecuada.

\section{Bibliografía}

1. Prein J, Beyer M. Management of infection and nonunion in mandibular fractures. Oral Maxillofac Surg Clin North Am 1990;2:187-94.

2. Schenk R, Willenegger $\mathrm{H}$. Histology of fracture repair and non-union. AO Bull 1978 .

3. Mathog RH, Toma V, Clayman L. Nonunion of the mandible: An analysis of contributing factors. J Oral Maxillofac Surg 2000;58:746-52.

4. Rittmann WW, Perren SM. Cortical bone healing after internal fixation and infection. Berlín, Springer 1974.

5. Mathog RH, Boies LR. Nonunion of the mandible. Laryngoscope 1976;86:908.

6. Topazian RF, Goldberg MH. Management of infections of the oral and maxillofacial regions. Philadelphia. PA, Saunders 1981;232-48.

7. Anderson T, Alpert B. Experience with rigid fixation of mandibular fractures and inmediate function. J Oral Maxillofac Surg 1992;50:555.

8. Gustillo RB, Anderson JT. Prevention of infection in the treatment of one thousand and twenty-five open fractures of long bones: Retrospective and prospective analysis. J Bone Joint Surg Am 1976;58:453.

9. Prein J, Kellman RM. Rigid internal fixation of mandibular fractures-basics of AO technique. Otolaryngol Clin North Am 1987;20:441.

10. Bochlogyros PN. Nonunion of fractures of the mandible. J Maxillofac Surg 1985;13:189.

11. Hardesty RA, Coffey JA. Secondary craniomaxillofacial deformities. Clin Plast Surg 1992;19:275-300.
1. Specific Antibiotherapy.

2. In case of facial fractures, anatomic reduction.

3. Stable fixation with plates and titanium screws.

4. Use of autologous bone grafts taken from in the center of the fracture.

It is true that using an inter maxilla block as the only method of stabilization causes inflammation, but usually causes extensive reabsorbtion of the distal fragments of the fracture, which generally results in pseudoarthrosis. Internal fixation is important for complete treatment, assuring correct and stable occlusion.

Pseudoarthrosis treatment, especially when there is a bone defect, involves not only internal rigid fixation, but also autologous bone grafts that reconstruct the created bone gap. Any sequestrum o tissue fragment should be removed and the distal fragments of the fracture should be split (10).

Instability combined with weak osteosynthetic material or continual bone gap contamination in the presence of soft tissue defects regularly leads to chronic infected pseudoarthrosis. Abnormal fixation of just one screw can be responsible for chronic inflammation. The elected treatment in these cases usually consists of replacing osteo synthetic material with new titanium plates (according to the bridging zone, in some cases it is important to use plates that support the weight, for example the jaw) with antibiotic coverage or bone grafts if they are necessary.

\section{Conclusions}

Nowadays among the array of therapeutics available we count on precise methods of internal rigid fixation. Despite the sophistications mentioned, new cases of delayed bone consolidation at the center of the fracture that need complimentary treatment continue to arise. Prior to corrective surgery it is important to critically analyze the pathological process. When it comes time to propose a definitive treatment it is important to have complete and well documented physical examination, image techniques and knowledge of the surgical techniques in use. ${ }^{11}$

The inadequate stabilization of fractures treated conservatively or with rigid fixation methods lead to infection, pseudoarthrosis or both. The solution requires a stable fixation of the fracture. Depending on the created defect, necessary osteo synthesis or re-osteo synthesis should be accompanied by an autologous sponge bone graft restoring appropriate dental occlusion. 